\title{
CHEMICAL COMPONTS OF MOSO BAMBOO (PHYLLOSTACHYS HETEROCYCLA VAR. PUBSCENSE) CULM AT DIFFERENT AGES AND HEIGHTS
}

\author{
LIU, X. ${ }^{1,2}-$ GUAN, $X^{2}-$ GUO, M. ${ }^{1 *}$ \\ ${ }^{I}$ Material Science and Engineering College, Northeast Forestry University \\ 150040 Harbin, China \\ (e-mail: liuxueshen412@163.com) \\ ${ }^{2}$ College of Material Engineering, Fujian Agriculture and Forestry University \\ 350002 Fuzhou, China \\ (e-mail: guanxin1001@sina.com) \\ *Corresponding author \\ e-mail:gmh1964@126.com
}

(Received $9^{\text {th }}$ Dec 2018; accepted $4^{\text {th }}$ Mar 2019)

\begin{abstract}
Bamboo is an effective alternative material to alleviate the burden on wood supplies. Chemical components distributed in the gradient structure of bamboo culm are likely to be the determining factors in selecting the optimal application of bamboo. Bamboo culm exhibits a complicated chemical composition of in holocellulose, lignin, pentosan and extractives in the longitudinal direction of its culm cultivated for varying periods of time. In this study, the chemical constituents of moso bamboo were analyzed statistically at different heights cultivated for a minimum of 6 months to as long as 9 years. No significant impact on chemical components was found in the longitudinal direction of the bamboo culm. However, bamboo culm age should be taken into consideration in the trends of holocellulose, pentosan, lignin and extractives located in the inner, middle and outer layers. The moso bamboo cultivated from 3 to 5 years was optimal for industrial application. The yield percentage and difference between layers, in particular, are fundamentals for evaluating and improving the properties for bamboo products.
\end{abstract}

Keywords: extractives, holocellulose, lignin, pentosan

\section{Introduction}

Bamboo is mainly distributed in tropical and subtropical areas, the growing stock and yield of which in China is one of the highest worldwide (Mao et al., 2017; FAO, 2010). Bamboo is almost exclusively composed of cellulose, hemicellulose and lignin, which is quite similar to wood in chemical composition. As a fast-growing plant, bamboo is regarded as a huge renewable resource base to reduce stress on wood resources to some extent (Cao et al., 2014; Jiang et al., 2015; Cheng et al., 2015; Kaur et al., 2016). In traditional industries, bamboo utilization only occurs for primary products such as handplaited bamboo articles and daily necessities. In high-tech industries, bamboo charcoal fiber, pulp-making, bamboo-based composite lumber and bamboo vinegar present the outstanding value of bamboo (Sulaiman et al., 2005; Ahmad and Kamke, 2011; Sugesty et al., 2015; Han et al., 2017), which is intimately linked to the chemical details of bamboo.

Bamboo is a lignocellulosic biomass with a complicated network structure. Lignocellulosic cell walls in bamboo give it the majority of its properties. Due to the covalent linkages among cellulose, hemicellulose and lignin, the definitive structure of the three natural compositions is almost unfathomable (Guerra et al., 2006; Huang et al., 2016). The chemical constituents of bamboo are known to vary greatly depending on 
species, position within the culm and the age of the culm. The varieties, like Bambusa arundinacea, Dendrocalamus asper, Gigantochloa apus, and Phyllostachys heterocycla, are more common species of bamboo suited to large-scale comprehensive utilization (Jayanetti and Follett, 1998). In very general terms bamboo consists of 50$70 \%$ holocellulose and 20-25\% lignin (Fengel and Shao, 1984; Liese, 1987). Lignin is a highly complex non-crystalline molecule comprising of a large number of phenylpropane units. The structure of the lignin present in bamboo is unique, and undergoes changes during the elongation and ageing of the culm (Itoh, 1990). The lignin content is relatively high in the epidermal layer and at the top of bamboo (Jiang et al., 2006). Between 40 and 50 percent of the dry mass of bamboo is in the form of cellulose forming from the anhydrogluclose unit. Cellulose plays a main role in mechanical characteristics of bamboo culm, even for bamboo fiber. The lignification process of bamboo is from the epidermal layer to inner waxy layer, that is, there is less cellulose in the epidermal layer (Lin et al., 2002). Hemicelluloses, therefore, comprise mixtures of polysaccharides manufactured in bamboo from basic sugars such xylose, arabinose, glucomannan and galactose (Balakshin et al., 2011). 90\% of the hemicellulose is xylan with a structure intermediate between hardwood and softwood xylans. The distribution of hemicellulose content is in a reversal of that of lignin content (Peng et al., 2012; Peng and She, 2014). Bamboo also has minor amounts of resins, waxes and tannins (Chung and Wang, 2017).

Bamboo industries on chemical components have different requirements. The higher cellulose content the better it is for pulping and papermaking. In general, cellulose is also closely related to the strength and deformation of bamboo-based panels. However, this relationship may be masked by the presence of amounts of extractives. Also, abnormally high lignin fractions in bamboo may influence structures and properties, at least in the longitudinal axis of bamboo (Richard and Harries, 2015; Huang et al., 2017). Therefore, thorough understanding of distributed chemical components in bamboo to optimize the further processing technology is required.

\section{Materials and methods}

\section{Preparation}

Moso bamboo (Phyllostachys heterocycla var. pubscense) was obtained from Sanming bamboo stands $(27 \mathrm{~N}, 117 \mathrm{E})$ in Fujian province, China. After air drying, bamboo samples (inter node) were collected from 6-month-old to 9-year-old stemsections at three different heights above ground level (1, 3, and $5 \mathrm{~m})$, and also, on the basis of position which is outer, middle and inner layer of the bamboo stems. Outer layer is the epidermal layer, and inner layer is the waxy layer (Fig. 1). Dried samples were ground into powder with a particle size of 40-60 mesh for chemical analysis.

\section{Determination of chemical components}

The chemical characteristics of bamboo were determined according to the national standards outlined in GB test methods. Holocellulose content was determined based on GB/T 2677.10-1995 Fibrous Raw Material (or FRM for short) - Determination of Holocellulose (GB, 1995). The lignin content was determined following the GB/T 2677.8-1994 FRM - Determination of Acid-insoluble Lignin (GB, 1994b). Pentosan content was determined in accordance with GB/T 2677.9-1994 FRM-Determination of 
Pentosan (GB, 1994c). The determination of extractives was carried out following GB/T 2677.6-1994 FRM-Determination of solvent extractives (GB, 1994a) and GB/T 2677.5-1993 FRM - Determination of One Percent Sodium Hydroxide Solubility (GB, 1993). The number of replicates was five, and the analyses of variance by Statistica 6 were used.

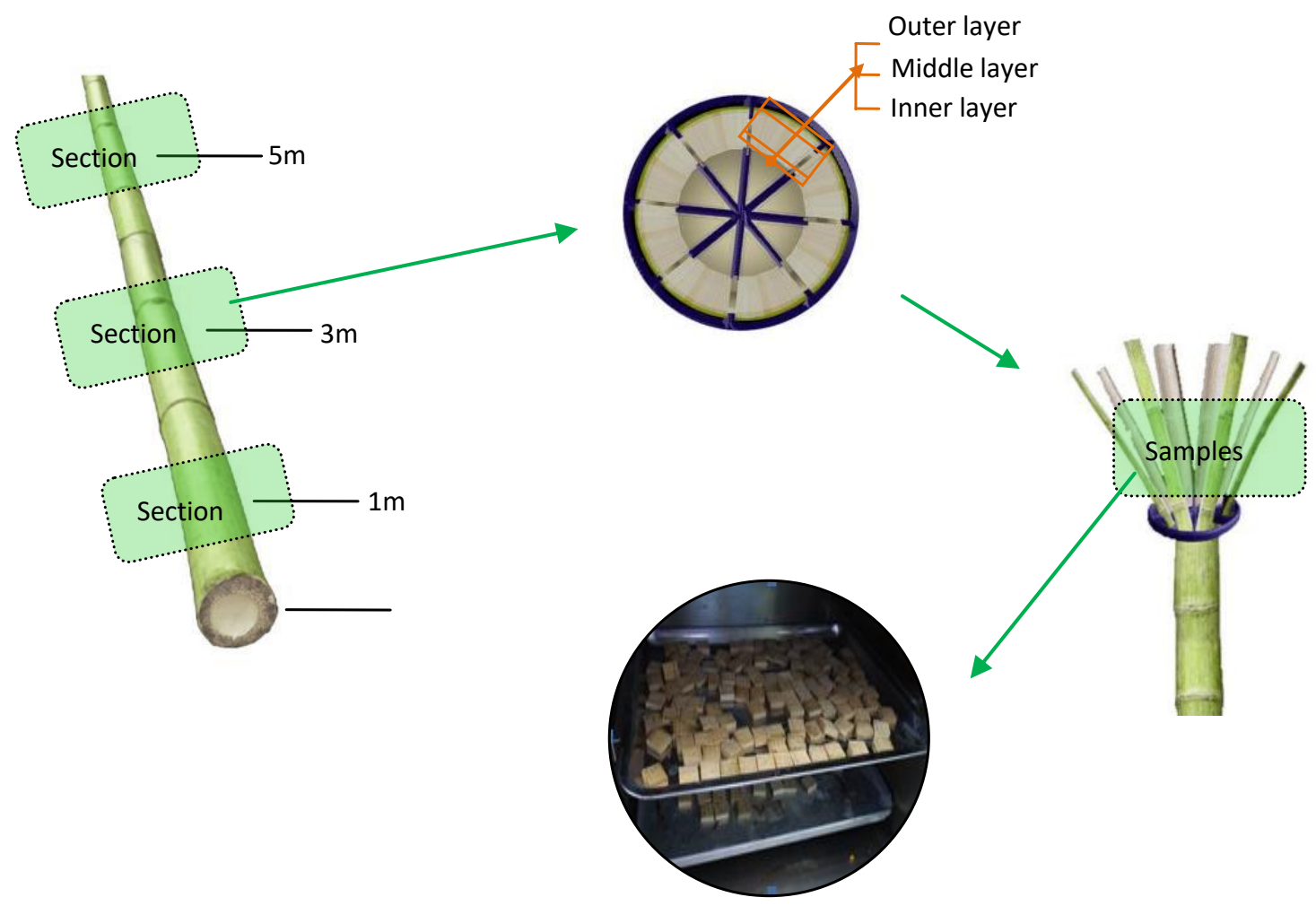

Figure 1. Preparation of bamboo samples

\section{Results}

\section{Chemical characteristics at different heights}

The chemical constitution of inner, middle and outer layer in the moso bamboo stems at different heights was determined respectively. The analysis of variance (ANOVA) on holocellulose, lignin, pentosan and extractives are showed in Table 1. There are no significant differences in chemical composition in the longitudinal direction of bamboo stems.

Table 1. Summary result for analysis of variance for chemical components at different heights

\begin{tabular}{c|c|c|c|c|c}
\hline \multirow{2}{*}{ Position } & \multicolumn{5}{|c}{ P-value } \\
\cline { 2 - 6 } & Holocellulose & Lignin & Pentosan & $\begin{array}{c}\text { 1\% sodium } \\
\text { hydroxide } \\
\text { extractives }\end{array}$ & $\begin{array}{c}\text { Solvent } \\
\text { extractives }\end{array}$ \\
\hline Inner & 0.750284 & 0.091319 & 0.991868 & 0.841184 & 0.697808 \\
Middle & 0.97058 & 0.24962 & 0.987907 & 0.403769 & 0.536052 \\
Outer & 0.843169 & 0.335781 & 0.863107 & 0.95569 & 0.509231 \\
\hline
\end{tabular}




\section{Chemical characteristics at different ages}

The chemical constitution of inner, middle and outer layer in the moso bamboo stems at different ages was determined respectively. The analysis of variance (ANOVA) on holocellulose, lignin, pentosan and extractives are showed in Table 2. Nearly all the chemical components for different layers shows significant differences among the culm age, except the lignin content in the inner and outer layer. Therefore, it is extremely valuable to perform trend analysis.

Table 2. Summary result for analysis of variance for chemical components at different ages

\begin{tabular}{c|c|c|c|c|c}
\hline \multirow{2}{*}{ Position } & \multicolumn{5}{|c}{ P-value } \\
\cline { 2 - 6 } & Holocellulose & Lignin & Pentosan & $\begin{array}{c}\text { 1\% sodium } \\
\text { hydroxide } \\
\text { extractives }\end{array}$ & $\begin{array}{c}\text { Solvent } \\
\text { extractives }\end{array}$ \\
\hline Inner & 0.00098 & 0.289121 & 0.002851 & 0.005266 & 0.004758 \\
Middle & 0.002666 & 0.028988 & 0.000192 & 0.017753 & $6.76 \mathrm{E}-05$ \\
Outer & 0.021891 & 0.251166 & 0.020283 & $2.76 \mathrm{E}-07$ & 0.000511 \\
\hline
\end{tabular}

The yield trends of holocellulose in the inner, middle and outer layer are showed in Figure 2 from 6-month-old to 9-year-old. The holocellulose content in middle layer is more than that in inner and outer layer in three years. However, holocellulose content in outer layer increases since 5-year-od, even more than that in middle layer. Meanwhile, there is a decreasing trend in percentage difference among the three layers. Considering there is no significance level along the height, the average of each layer at different height is carried out to determine the comparative benefit. The changing trends of holocellulose content for inner and outer layer are the similar, and peak at the fifth year.

The variation of lignin content in the three layers is shown respectively in Figure 3 from 6-month-old to 9-year-old. Inner layer has a great similarity in lignin content compared to middle layer. However, only the middle layer shows a significant relativity for lignin content. In the middle layer, lignin content increases slightly from the sixth month to the third year, and then it is nearly at a constant level.

Here is that the pentosan content as a whole increases from the outer layer to the inner layer (Fig. 4). As such, there is much comparability between the inner layer and middle layer. Pentosan content reaches up to the maximum value in the fifth year and gets the minimum value in the seventh year. In the third year, however, the global minimal value of pentosan content appears in the outer layer.

The $1 \%$ sodium hydroxide extractive of bamboo is closely related to decay resistance, which is mainly composed of tannin, pigment, alkaloid, saccharine, starch, degraded hemicellulose and lignin, etc (Jiang et al., 2015). The variation trend in the inner layer is similar to that in the middle layer, but different from that in the outer layer (Fig. 5). The yield is ranging from $19.38 \%$ to $35.06 \%$. The $1 \%$ sodium hydroxide extractive in the inner layer is more than that in other two layers except in the seventh year, and the tendency is almost smooth before the five year and changes suddenly in the seventh year.

The changing trend of solvent extractives in the inner layer is similar with that in the outer layer, and has a little difference from that in the middle layer (Fig. 6). The lowest content of solvent extractives is set in the 5-year-old bamboo stems for each layer. The 
variation of solvent extractives is similar between each layer after the third year. In contrast, there is less extractives in the middle layer than that in other two layers.

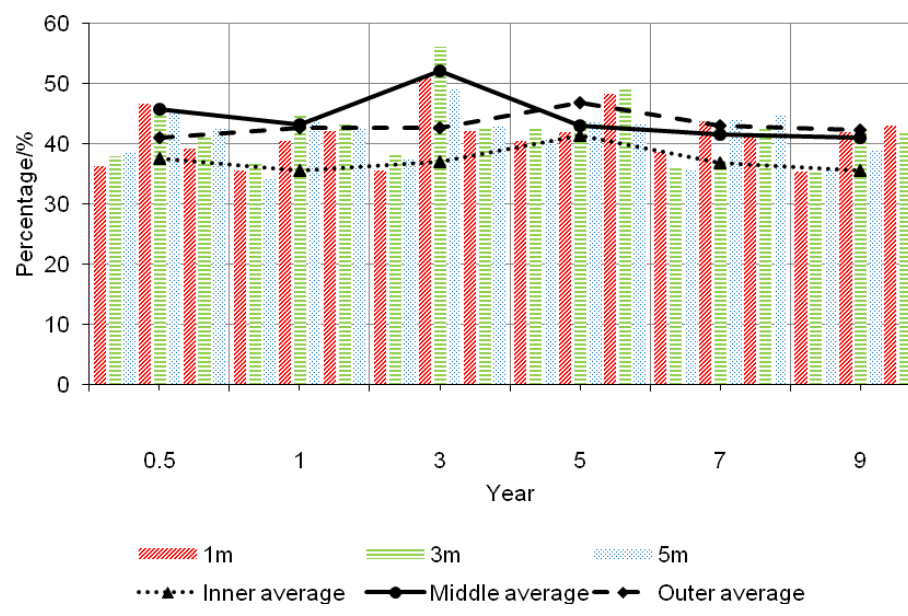

Figure 2. Variation of holocellulose content

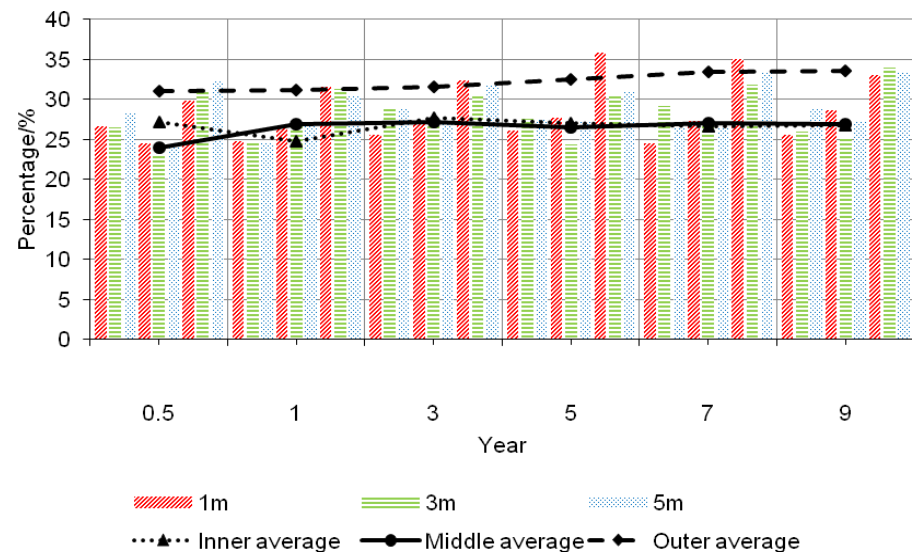

Figure 3. Variation of lignin content

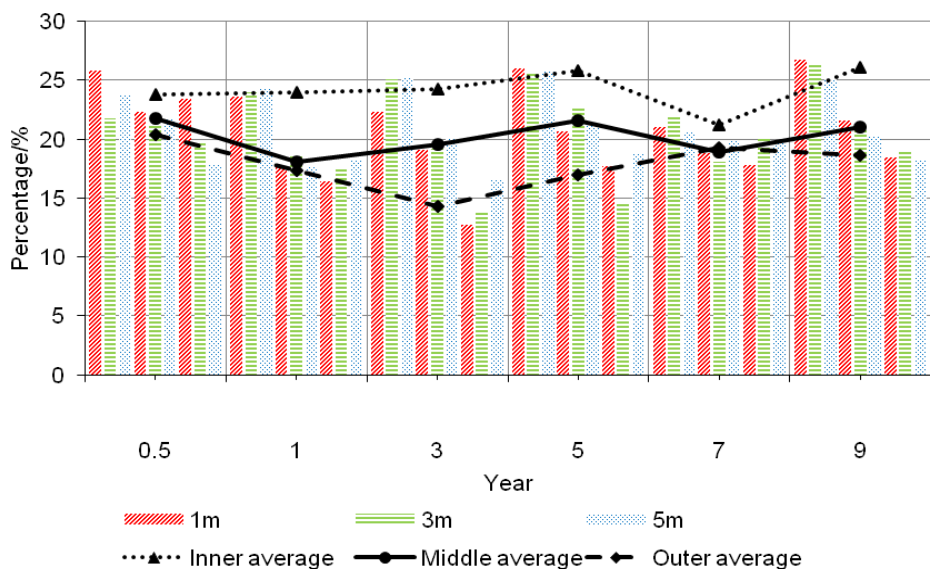

Figure 4. Variation of pentosan content 


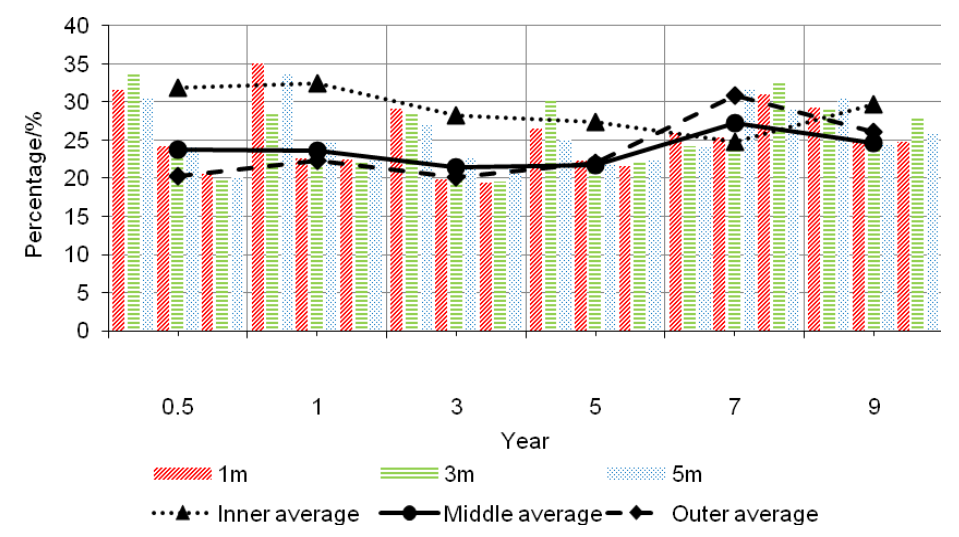

Figure 5. Variation of $1 \%$ sodium hydroxide extractives

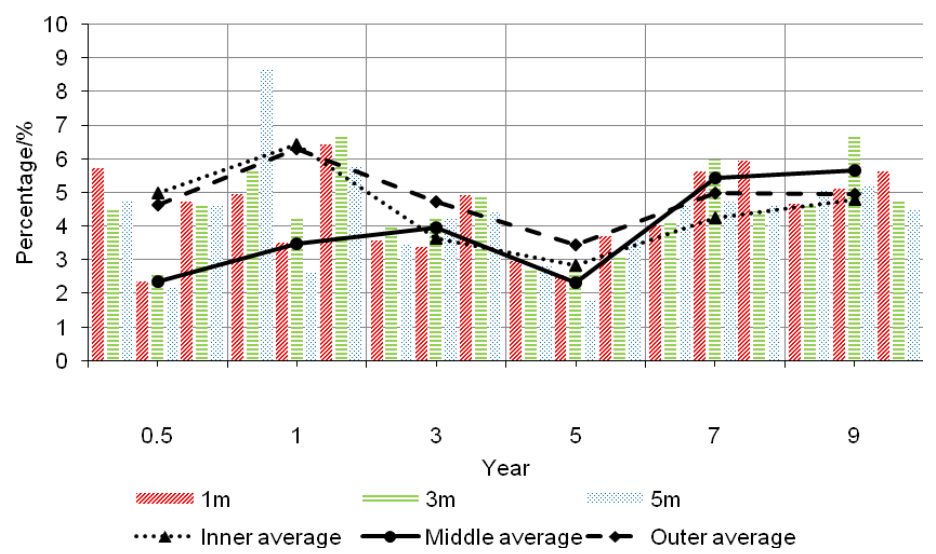

Figure 6. Variation of solvent extractives

\section{Discussion}

It should be noted that the $-\mathrm{OH}$ groups of the cellulose molecules which give rise to hydrogen bonding are also highly attractive to moisture. Below the fiber saturation point, a subsequent dimensional change was occurred (Anokye et al., 2014). Bamboo strips are liable to distortion such as twist and bow, which has a strong influence with mechanical properties (Saito and Arima, 2002; Kamruzzaman et al., 2008). According to the findings, the distribution of chemical components in the longitudinal direction of bamboo stems should not be the reason to warping. That is, the distortion of bamboo strips may be due to the gradient fibrous structure (Chen et al., 2018).

However, the chemical constituents are fundamental to physical and mechanical properties of bamboo. The holocellulose content in middle layer reaches the maximum of all yield percentage at the third year, which has potential for use as dissolving pulp compared to softwoods (Lovell, 1945). As the panel practice, 3-year-old bamboo is optimum for tangential bamboo sliver, and 5-year-old bamboo is a good choice for radial bamboo sliver in regard of dimensional stability (Sinha and Miyamoto, 2014; Suthon, 2016; Li et al., 2018). A markedly higher proportion of lignin is in the outer layer, which is consistent with the outcome of lignification process (Lin et al., 2002; Tsuyama et al., 2017). For the 3-year-old and 5-year-old bamboo culm, there is obvious 
difference in pentosan content among the three layers. The yield of pentosan in the outer layer is less than the inner layer and middle layer. Pentosan can not only lower moisture absorption of bamboo, it can also improve the toughness of bamboo (Das and Chakraborty, 2008; Banik et al., 2017). Therefore, failure region should be close to the outer layer when a force is applied perpendicular to grain. However, none of studies has been reported from this point at least for now. The extractive contents of moso bamboo are higher than that of softwood and hardwood. Therefore, it is more complicated for preservative treatment (Shah et al., 2018). The high yield percentage of $1 \%$ sodium hydroxide extractive indicates that there are more hemicellulose and lignin with lower molecular weight. The solvent extractives consist of wax, fatty acid, essential oil and so on. Higher percentage of solvent extractives has a negative effect on pulping process (Muhammad et al., 2013).

\section{Conclusions}

1. Heights have no significant impact on chemical constituents for the inner, middle and outer layer respectively. However, bamboo culm age is closely associated with holocellulose, pentosan, lignin and extractives.

2. The maximum yield of holocellulose is found in the middle layer of the 3-year-old bamboo culm. But it is obvious that the holocellulose contents in the three layers are similar at the fifth year. For lignin content, there is almost no difference in each layer between the third year and the fifth year. There is a clear distinction for percentage of pentosan in the three layers from the third year to the fifth year, which has a potential impact on strength. The lowest percentage of extractives presents in the fifth year. However, the percentage of $1 \%$ sodium hydroxide extractives changes hardly from the third year to the fifth year.

3. For the practical application, it is impossible to get a desired percentage of chemical components of moso bamboo in a particular culm age. However, the optimization of culm age could be accomplished in terms of the different performance requirements of bamboo products.

Acknowledgements. This study was supported by National Natural Science Foundation (NSFC) of China (Grant \#: 31600455).

\section{REFERENCES}

[1] Ahmad, M., Kamke, F. A. (2011): Properties of parallel strand lumber from Calcutta bamboo Dendrocalamus strictus. - Wood Sci. Technol. 45(1): 63-72.

[2] Anokye, R., Kalong, R. M., Bakar, E. S., Ratnasingam, J., Jawaid, M., Awang, K. (2014): Variations in moisture content affect the shrinkage of Gigantochloa scortechinii and Bambusa vulagris at different heights of the bamboo culm. - BioResources 9(4): 74847493.

[3] Balakshin, M., Capanema, E., Gracz, H., Chang, H. M., Jameel, H. (2011): Quantification of lignin-carbohydrate linkages with high-resolution NMR spectroscopy. - Planta. 233(6): 1097-1110.

[4] Banik, N., Dey, V., Sastry, G. R. K. (2017): An overview of lignin \& hemicellulose effect upon biodegradable bamboo fiber composites due to moisture. - Mater. Today P 4(2): 3222-3232. 
[5] Cao, S. L., Ma, X. J., Lin, L., Huang, L. L., Chen, L. H. (2014): Morphological and chemical characterization of green bamboo (Dendrocalamopsis oldhami (Munro) Keng f.) for dissolving pulp production. - BioResources 9(3): 4528-4539.

[6] Chen, G. W., Luo, H. Y., Wu, S. J., Guan, J., Luo, J., Zhao, T. S. (2018): Flexural deformation and fracture behaviors of bamboo with gradient hierarchical fibrous structure and water content. - Compos. Sci. Technol. 157(22): 126-133.

[7] Cheng, L., Adhikari, S., Wang, Z. H., Ding, Y. L. (2015): Characterization of bamboo species at different ages and bio-oil production. - J. Anal. Appl. Pyrol. 116: 215-222.

[8] Chung, M. J., Wang, S. Y. (2017): Effects of peeling and steam-heating treatment on basic properties of two types of bamboo culms (Phullostachys makinoi and Phyllostachys pubescens. - J. Wood Sci. 63(5): 473-482.

[9] Das, M., Chakraborty, D. (2008): Evaluation of improvement of physical and mechanical properties of bamboo fibers due to alkali treatment. - J. Appl. Polym. Sci. 107(1): 522527.

[10] FAO (2010): Global Forest Resources Assessment: Main Report. - Food and Agriculture Organization of the United Nations, Rome.

[11] Fengel, D., Shao, X. (1984): A chemical and ultrastructural study of the bamboo species Phyllostachys makinoi Hay. - Wood Sci. Technol. 18(2): 103-112.

[12] GB (1993): Raw Material. Determination of One Percent Sodium Hydroxide Solubility. Chinese Standard, GB/T 2677.5. - Standards Press of China, Beijing, China.

[13] GB (1994a): Raw Material. Determination of Solvent Extractives. Chinese Standard, GB/T 2677.6. - Standards Press of China, Beijing, China.

[14] GB (1994b): Raw Material. Determination of Acid-insoluble Lignin. Chinese Standard, GB/T 2677.8. - Standards Press of China, Beijing, China.

[15] GB (1994c): Raw Material. Determination of Pentosan. Chinese Standard, GB/T 2677.9. - Standards Press of China, Beijing, China.

[16] GB (1995): Raw Material. Determination of Holocellulose. Chinese Standard, GB/T 2677.10. - Standards Press of China, Beijing, China.

[17] Guerra, A., Filpponen, I., Lucia, L. A., Saquing, C., Baumberger, S., Argyropoulos, D. S. (2006): Toward a better understanding of the lignin isolation process from wood. - J. Agr. Food Chem. 54(16): 5939-5947.

[18] Han, Q. G., Yi, Z., Wang, F. X., Wu, Y. M., Wang, L. M. (2017): Preparation of bamboo carbon fiber and sandwich-like bamboo carbon fiber@ $\mathrm{SnO}_{2} @$ carbon composites and their potential application in structural lithium-ion battery anodes. - J. Alloy. Compd. 709: 227-233.

[19] Huang, C. X., He, J., Du, L. T., Min, D. Y., Yong, Q. (2016): Structural characterization of the lignins from the green and yellow bamboo of bamboo culm (Phyllostachys pubescens). - J. Wood Chem. Technol. 36(3): 157-172.

[20] Huang, Z. J., Sun, Y. M., Musso, F. (2017): Experimental study on bamboo hygrothermal properties and the impact of bamboo-based panel process. - Constr. Build. Mater. 155: $1112-1125$.

[21] Itoh, T. (1990): Lignification of bamboo (Phyllostachys heterocycla Mitf.) during its grow. - Holzforschung 44(3): 191-200.

[22] Jayanetti, D. L., Follett, P. R. (1998): Bamboo in Construction. - South Bucks Press, Bucks, UK.

[23] Jiang, Y., Nie, S. X., Liang, D. S., Zhang, N., Wang, S. F., Song, X. P. (2015): Effects of alkaline hydrogen peroxide pre-extraction on bamboo lignin chemistry and other bamboo chemical components. - BioResources 10(4): 6332-6347.

[24] Jiang, Z. H., Yu, W. J., Yu, Y. L. (2006): Analysis of chemical components of bamboo wood and characteristic of surface performance. - J. Northeast For. Univ. 34(4): 1-2, 6.

[25] Kamruzzaman, M., Saha, S. K., Bose, A. K., Islam, M. N. (2008): Effects of age and height on physical and mechanical properties of bamboo. - J. Trop. For. Sci. 20(3): 211217. 
[26] Kaur, P. J., Satya, S., Pant, K. K., Naik, S. N., Kardam, V. (2016): Chemical characterization and decay resistance analysis of smoke treated bamboo species. - Holz. Roh. Werkst. 74(4): 625-628.

[27] Li, H. T., Wu, G., Zhang, Q. S., Deeks, A. J., Su, J. W. (2018): Ultimate bending capacity evaluation of laminated bamboo lumber beams. - Constr. Build. Mater. 160: 365-375.

[28] Liese, W. (1987): Research on bamboo. - Wood Sci. Technol. 21(3): 189-209.

[29] Lin, J. X., He, X. Q., Hu, Y. X., Kuang, T. Y., Ceulemans, R. (2002): Lignification and lignin heterogeneity for various age classes of bamboo (Phyllostachys pubescens) stems. - Physiologica Plantarum 114(2): 296-302.

[30] Lovell, E. L. (1945): Fibrous holocellulose from softwoods. - Ind. Eng. Chem. 37(11): 1034-1037.

[31] Mao, F. J., Zhou, G. M., Li, P. H., Du, H. Q., Xu, X. J., Shi, Y. J., Mo, L. F., Zhou, Y. F., Tu, G. Q. (2017): Optimizing selective cutting strategies for maximum carbon stocks and yield of Moso bamboo forest using BIOME-BGC model. - J. Environ. Manage. 191: 126-135.

[32] Muhammad, N., Man, Z., Bustam, M. A., Mutalib, M. I. A., Rafiq, S. (2013): Investigations of novel nitrile-based ionic liquids as pre-treatment solvent for extraction of lignin from bamboo biomass. - J. Ind. Eng. Chem. 19(1): 207-214.

[33] Peng, H., Zhang, J. S., Liu, Y. H., Liu, D. T., Yu, Z. P., Wan, Y. Q., Ruan, R. (2012): Structural characterization of hemicellulosic polysaccharides isolated from bamboo (Phyllostachys pubescens Mazel). - Curr. Org. Chem. 16(16): 1855-1862.

[34] Peng, P., She, D. (2014): Isolation, structural characterization, and potential applications of hemicellulose from bamboo: A review. - Carbohyd. Polym. 112(4): 701-720.

[35] Richard, M. J., Harries, K. A. (2015): On inherent bending in tension tests of bamboo. Wood Sci. Technol. 49: 99-119.

[36] Saito, Y., Arima, T. (2002): Deformation under a repetition of moisturizing and drying of bamboo subjected to a set in bending. - J. Wood Sci. 48(2): 114-118.

[37] Shah, D. U., Sharma, B., Ramage, M. H. (2018): Processing bamboo for structural composites: Influence of preservative treatments on surface and interface properties. $-\mathrm{J}$. Adhes. 5: 9.

[38] Sinha, A., Miyamoto, B. T. (2014): Lateral load carrying capacity of laminated bamboo lumber and oriented strand board connections. - J. Mater. Civil Eng. 26(4): 741-747.

[39] Sugesty, S., Kardiansyah, T., Hardiani, H. (2015): Bamboo as raw materials for dissolving pulp with environmental friendly technology for rayon fiber. - Procedia Chem. 17: 194-199.

[40] Sulaiman, O., Murphy, R. J., Hashim, R., Gritsch, C. S. (2005): The inhibition of microbial growth by bamboo vinegar. - J. Bamboo Rattan. 4(1): 71-80.

[41] Suthon, S. (2016): Utilization of bamboo as lightweight sandwich panels. - Mater. SciMedzg. 22(1): 60-64.

[42] Tsuyama, T., Shimada, N., Motoda, T., Matsushita, Y., Kijidani, Y., Fukushima, K., Kamei, I. (2017): Lignification in development culms of bamboo Simobambusa tootsik. J. Wood Sci. 63(6): 551-559. 


\section{APPENDIX}

Appendix 1. Analysis of variance for chemical components at different heights

\begin{tabular}{|c|c|c|c|c|c|c|c|}
\hline & & & Sum of squares & df & Mean square & $\mathbf{F}$ & P-value \\
\hline \multirow{3}{*}{ Holocellulose } & Inner & $\begin{array}{c}\text { Between groups } \\
\text { Within groups } \\
\text { Total }\end{array}$ & $\begin{array}{c}3.3258544 \\
83.44475 \\
86.70329 \\
\end{array}$ & $\begin{array}{c}2 \\
15 \\
17\end{array}$ & $\begin{array}{l}1.629272 \\
5.562983\end{array}$ & 0.292877 & 0.750284 \\
\hline & Middle & $\begin{array}{c}\text { Between groups } \\
\text { Within groups } \\
\text { Total }\end{array}$ & $\begin{array}{c}1.3279 \\
332.8572 \\
334.1851\end{array}$ & $\begin{array}{c}2 \\
15 \\
17\end{array}$ & $\begin{array}{c}0.66395 \\
22.19048\end{array}$ & 0.02992 & 0.97058 \\
\hline & Outer & $\begin{array}{c}\text { Between groups } \\
\text { Within groups } \\
\text { Total }\end{array}$ & $\begin{array}{c}2.1411 \\
93.06835 \\
95.20945\end{array}$ & $\begin{array}{c}2 \\
15 \\
17\end{array}$ & $\begin{array}{c}1.07055 \\
6.204557\end{array}$ & 0.172543 & 0.843169 \\
\hline \multirow{3}{*}{ Lignin } & Inner & $\begin{array}{c}\text { Between groups } \\
\text { Within groups } \\
\text { Total }\end{array}$ & $\begin{array}{c}12.03063 \\
32.00357 \\
44.0342\end{array}$ & $\begin{array}{c}2 \\
15 \\
17\end{array}$ & $\begin{array}{l}6.015317 \\
2.133571\end{array}$ & 2.819365 & 0.091319 \\
\hline & Middle & $\begin{array}{c}\text { Between groups } \\
\text { Within groups } \\
\text { Total }\end{array}$ & $\begin{array}{l}6.374633 \\
31.36062 \\
37.73525\end{array}$ & $\begin{array}{c}2 \\
15 \\
17\end{array}$ & $\begin{array}{l}3.187317 \\
2.090708\end{array}$ & 1.524516 & 0.24962 \\
\hline & Outer & $\begin{array}{l}\text { Between groups } \\
\text { Within groups } \\
\text { Total }\end{array}$ & $\begin{array}{l}6.415011 \\
40.95777 \\
47.37278\end{array}$ & $\begin{array}{c}2 \\
15 \\
17\end{array}$ & $\begin{array}{l}3.207506 \\
2.730518\end{array}$ & 1.174688 & 0.335781 \\
\hline \multirow{3}{*}{ Pentosan } & Inner & $\begin{array}{c}\text { Between groups } \\
\text { Within groups } \\
\text { Total }\end{array}$ & $\begin{array}{c}0.068011 \\
62.4389 \\
62.50691\end{array}$ & $\begin{array}{c}2 \\
15 \\
17\end{array}$ & $\begin{array}{l}0.034006 \\
4.162593\end{array}$ & 0.008169 & 0.991868 \\
\hline & Middle & $\begin{array}{c}\text { Between groups } \\
\text { Within groups } \\
\text { Total }\end{array}$ & $\begin{array}{c}0.0673 \\
41.4537 \\
41.521\end{array}$ & $\begin{array}{c}2 \\
15 \\
17\end{array}$ & $\begin{array}{l}0.03365 \\
2.76358\end{array}$ & 0.012176 & 0.987907 \\
\hline & Outer & $\begin{array}{c}\text { Between groups } \\
\text { Within groups } \\
\text { Total }\end{array}$ & $\begin{array}{c}2.041733 \\
102.9993 \\
105.041\end{array}$ & $\begin{array}{c}2 \\
15 \\
17\end{array}$ & $\begin{array}{l}1.020867 \\
6.866618\end{array}$ & 0.148671 & 0.863107 \\
\hline \multirow{3}{*}{$\begin{array}{l}1 \% \text { sodium } \\
\text { hydroxide } \\
\text { extractives }\end{array}$} & Inner & $\begin{array}{c}\text { Between groups } \\
\text { Within groups } \\
\text { Total }\end{array}$ & $\begin{array}{l}4.010478 \\
171.9231 \\
175.9336\end{array}$ & $\begin{array}{c}2 \\
15 \\
17\end{array}$ & $\begin{array}{l}2.005239 \\
11.46154\end{array}$ & 0.174954 & 0.841184 \\
\hline & Middle & $\begin{array}{c}\text { Between groups } \\
\text { Within groups } \\
\text { Total }\end{array}$ & $\begin{array}{c}11.95551 \\
93.0126 \\
104.9681\end{array}$ & $\begin{array}{c}2 \\
15 \\
17\end{array}$ & $\begin{array}{c}5.977756 \\
6.20084\end{array}$ & 0.964024 & 0.403769 \\
\hline & Outer & $\begin{array}{c}\text { Between groups } \\
\text { Within groups } \\
\text { Total }\end{array}$ & $\begin{array}{c}1.6471 \\
271.7434 \\
273.3905\end{array}$ & $\begin{array}{c}2 \\
15 \\
17\end{array}$ & $\begin{array}{c}0.82355 \\
18.11622\end{array}$ & 0.045459 & 0.95569 \\
\hline \multirow{3}{*}{$\begin{array}{c}\text { Solvent } \\
\text { extractives }\end{array}$} & Inner & $\begin{array}{c}\text { Between groups } \\
\text { Within groups } \\
\text { Total }\end{array}$ & $\begin{array}{l}1.478633 \\
30.08762 \\
31.56625\end{array}$ & $\begin{array}{c}2 \\
15 \\
17\end{array}$ & $\begin{array}{l}0.739317 \\
2.005841\end{array}$ & 0.368582 & 0.697808 \\
\hline & Middle & $\begin{array}{c}\text { Between groups } \\
\text { Within groups } \\
\text { Total }\end{array}$ & $\begin{array}{l}2.875233 \\
33.16682 \\
36.04205 \\
\end{array}$ & $\begin{array}{c}2 \\
15 \\
17 \\
\end{array}$ & $\begin{array}{l}1.437617 \\
2.211121\end{array}$ & 0.650175 & 0.536052 \\
\hline & Outer & $\begin{array}{l}\text { Between groups } \\
\text { Within groups } \\
\text { Total }\end{array}$ & $\begin{array}{l}1.310978 \\
13.92392 \\
15.23489\end{array}$ & $\begin{array}{c}2 \\
15 \\
17\end{array}$ & $\begin{array}{l}0.655489 \\
0.928261\end{array}$ & 0.706147 & 0.509231 \\
\hline
\end{tabular}


Appendix 2. Analysis of variance for chemical components at different ages

\begin{tabular}{|c|c|c|c|c|c|c|c|}
\hline & & & Sum of squares & df & Mean square & $\mathbf{F}$ & P-value \\
\hline \multirow{3}{*}{ Holocellulose } & Inner & $\begin{array}{c}\text { Between groups } \\
\text { Within groups } \\
\text { Total }\end{array}$ & $\begin{array}{l}68.34063 \\
18.36267 \\
86.70329\end{array}$ & $\begin{array}{c}5 \\
12 \\
17\end{array}$ & $\begin{array}{l}13.66813 \\
1.530222\end{array}$ & 8.932118 & 0.00098 \\
\hline & Middle & $\begin{array}{l}\text { Between groups } \\
\text { Within groups } \\
\text { Total }\end{array}$ & $\begin{array}{l}249.6375 \\
84.54753 \\
334.1851\end{array}$ & $\begin{array}{c}5 \\
12 \\
17\end{array}$ & $\begin{array}{c}49.9275 \\
7.045628\end{array}$ & 7.08631 & 0.002666 \\
\hline & Outer & $\begin{array}{c}\text { Between groups } \\
\text { Within groups } \\
\text { Total }\end{array}$ & $\begin{array}{l}59.78872 \\
35.42073 \\
95.20945\end{array}$ & $\begin{array}{c}5 \\
12 \\
17 \\
\end{array}$ & $\begin{array}{l}11.95774 \\
2.951728\end{array}$ & 04.0511 & 0.021891 \\
\hline \multirow{3}{*}{ Lignin } & Inner & $\begin{array}{c}\text { Between groups } \\
\text { Within groups } \\
\text { Total } \\
\end{array}$ & $\begin{array}{c}16.29027 \\
27.74393 \\
44.0342 \\
\end{array}$ & $\begin{array}{c}5 \\
12 \\
17 \\
\end{array}$ & $\begin{array}{l}3.258053 \\
2.311994\end{array}$ & 1.409196 & 0.289121 \\
\hline & Middle & $\begin{array}{c}\text { Between groups } \\
\text { Within groups } \\
\text { Total } \\
\end{array}$ & $\begin{array}{l}22.92898 \\
14.80627 \\
37.73525 \\
\end{array}$ & $\begin{array}{c}5 \\
12 \\
17 \\
\end{array}$ & $\begin{array}{l}4.585797 \\
1.233856\end{array}$ & 3.71664 & 0.028988 \\
\hline & Outer & $\begin{array}{c}\text { Between groups } \\
\text { Within groups } \\
\text { Total }\end{array}$ & $\begin{array}{c}18.47778 \\
28.895 \\
47.37278 \\
\end{array}$ & $\begin{array}{c}5 \\
12 \\
17 \\
\end{array}$ & $\begin{array}{l}3.695556 \\
2.407917\end{array}$ & 1.534752 & 0.251166 \\
\hline \multirow{3}{*}{ Pentosan } & Inner & $\begin{array}{c}\text { Between groups } \\
\text { Within groups } \\
\text { Total }\end{array}$ & $\begin{array}{l}46.50238 \\
16.00453 \\
62.50691\end{array}$ & $\begin{array}{c}5 \\
12 \\
17 \\
\end{array}$ & $\begin{array}{l}9.300476 \\
1.333711\end{array}$ & 6.973381 & 0.002851 \\
\hline & Middle & $\begin{array}{c}\text { Between groups } \\
\text { Within groups } \\
\text { Total }\end{array}$ & $\begin{array}{c}34.90713 \\
6.613867 \\
41.521\end{array}$ & $\begin{array}{c}5 \\
12 \\
17\end{array}$ & $\begin{array}{l}6.981427 \\
0.551156\end{array}$ & 12.66689 & 0.000192 \\
\hline & Outer & $\begin{array}{c}\text { Between groups } \\
\text { Within groups } \\
\text { Total }\end{array}$ & $\begin{array}{l}66.5198 \\
38.5212 \\
105.041\end{array}$ & $\begin{array}{c}5 \\
12 \\
17\end{array}$ & $\begin{array}{c}13.30396 \\
3.2101\end{array}$ & 4.144407 & 0.020283 \\
\hline \multirow{3}{*}{$\begin{array}{l}1 \% \text { sodium } \\
\text { hydroxide } \\
\text { extractives }\end{array}$} & Inner & $\begin{array}{l}\text { Between groups } \\
\text { Within groups } \\
\text { Total }\end{array}$ & $\begin{array}{l}125.6189 \\
50.31467 \\
175.9336\end{array}$ & $\begin{array}{c}5 \\
12 \\
17\end{array}$ & $\begin{array}{l}25.12378 \\
4.192889\end{array}$ & 5.991998 & 0.005266 \\
\hline & Middle & $\begin{array}{l}\text { Between groups } \\
\text { Within groups } \\
\text { Total }\end{array}$ & $\begin{array}{l}67.42418 \\
37.54393 \\
104.9681\end{array}$ & $\begin{array}{c}5 \\
12 \\
17\end{array}$ & $\begin{array}{l}13.48484 \\
3.128661\end{array}$ & 4.310098 & 0.017753 \\
\hline & Outer & $\begin{array}{c}\text { Between groups } \\
\text { Within groups } \\
\text { Total }\end{array}$ & $\begin{array}{l}259.1318 \\
14.25867 \\
273.3905\end{array}$ & $\begin{array}{c}5 \\
12 \\
17\end{array}$ & $\begin{array}{l}51.82636 \\
1.188222\end{array}$ & 43.61672 & $2.76 \mathrm{E}-07$ \\
\hline \multirow{3}{*}{$\begin{array}{c}\text { Solvent } \\
\text { extractives }\end{array}$} & Inner & $\begin{array}{c}\text { Between groups } \\
\text { Within groups } \\
\text { Total }\end{array}$ & $\begin{array}{l}22.70292 \\
8.863333 \\
31.56625\end{array}$ & $\begin{array}{c}5 \\
12 \\
17\end{array}$ & $\begin{array}{l}4.540583 \\
0.738611\end{array}$ & 6.147461 & 0.004758 \\
\hline & Middle & $\begin{array}{l}\text { Between groups } \\
\text { Within groups } \\
\text { Total }\end{array}$ & $\begin{array}{l}31.24992 \\
4.792133 \\
36.04205\end{array}$ & $\begin{array}{c}5 \\
12 \\
17\end{array}$ & $\begin{array}{l}6.249983 \\
0.399344\end{array}$ & 15.65061 & $6.76 \mathrm{E}-05$ \\
\hline & Outer & $\begin{array}{c}\text { Between groups } \\
\text { Within groups } \\
\text { Total }\end{array}$ & $\begin{array}{l}12.35763 \\
2.877267 \\
15.23489\end{array}$ & $\begin{array}{c}5 \\
12 \\
17\end{array}$ & $\begin{array}{l}2.471526 \\
0.239772\end{array}$ & 10.30781 & 0.000511 \\
\hline
\end{tabular}

